вывод, что Римская система воспитания была ярким примером социального воспитания, цель которого состояла в подготовке общественного деятеля. Кроме того, в статье раскрыты воспитательные идеи Древней Руси.

Ключевые слова: воспитание, системы воспитания, мировая цивилизация.

Serhii Cherniak,

PhD (Candidate of Pedagogical Sciences), associate professor, head of the Department of Legislative Proposals and Problems of Culture Financing, Ukrainian Centre for Cultural Studies, 21, I. Mazepy Str., Kyiv, Ukraine

\title{
EMERGENCE AND DEVELOPMENT OF EDUCATION IN THE WORLD CIVILIZATION
}

The article deals with the emergence and development of education in the world civilization. The author focuses on the fact that the need for education of children and young people originates from the primitive society. At the stage of the early matriarchy education was associated with the performance of everyday duties and was not allocated as particular social activities. The evolution of material relations between primitive people is considered to be an essential factor of the formation of education as a special kind of activities. At the stage of patriarchy education was considered as a form of social activities. Some literary compositions of Ancient East have been reviewed in the paper. It was concluded that family education was not enough to transfer the necessary system of knowledge and social experience. Besides, the systems of education at first schools of East (Mesopotamia, Egypt, Iran, India, China) have been described. Special attention is paid to the development of education in the ancient world. The most popular educational systems of Ancient Greece were Athenian and Spartan ones. The Athenian educational system is regarded as an ancestor of high spiritual culture, the formation of a harmonious person, whose main qualities were spiritual wealth, moral purity and physical perfection. The Spartan educational system was based on the physical training, hardening, formation of the strength of mind, craft, and discipline. Besides, the educational system and the pedagogical heritage of the Rome Empire have been reviewed in the article. It has been concluded that the Roman educational system was a great example of social education aimed at preparing public characters. In addition, some educational ideas of Ancient Rus have been revealed and described.

Keywords: education, education systems, world civilization.

Подано до редакиіï 13.04.2016

Рецензент: д. пед. н. Л. А. Онищук

\section{Божена Олегівна Буховець, аспірант кафедри теорії та методики фізичного виховання, лікувальної фізкультури та спортивної медицини, Південноукраӥнський національний педагогічний університет імені К. Д. Уиинського, вул. Фонтанська дорога, 4, м. Одеса, Украӥна}

Статтю присвячено проблемі визначення ефективності застосування методу Бобат як основної методики корекиії психофізичного стану дітей дошкільного віку з ураженням иеентральної нервової системи, враховуючи гендерні особливості. Для очінки ефективності проведення корекційних розвиваючих занять методом Бобат із урахуванням гендерних особливостей було розроблено та використано власну адаптовану шкалу «Карта - тест рухових можливостей дітей від Змісяџів до повноліття», яка визначає основні етапи психомоторного розвитку дитини. Враховуючи універсальність, доступність та інформативність изього тесту стало можливим оцінити ефективність застосування методу Бобат у корекиії психофізичного стану дітей дошкільного віку з ураженням центральної нервової системи.

Ключові слова: психомоторний розвиток, діти дошкільного віку, метод Бобат, иентральна нервова система, корекиійні розвиваючі заняття.

Постановка проблеми. У сучасному застосуванні корекційних заходів, спрямованих на відновлення рухової та психоемоційної сфер, виникає проблема вибору та застосування найбільш ефективних методик, які сприя- ють нормалізації рухової активності дітей з ураженням центральної нервової системи (ЦНС).

Перинатальні та постнатальні ураження нервової системи (НС), внаслідок впливу на плід різних чинників (патологія вагітності матері, інфекційні захворю- 
вання, родові травми, асфіксія, інтоксикація), припускають появу низки важких дегенеративних змін мозкової тканини нервової системи, які призводять до патологічних станів (параліч Ерба-Дюшенна, нижній параліч Дежерин-Клюмпке, дитячий церебральний параліч, гідро/мікро-цефалія) [6;13].

Діти, що мають органічні ураження НС різного генезу, потребують ранньої діагностики порушень та проведення своєчасних корекційних заходів. Раннє втручання - система комплексної міждисциплінарної сімейно- педагогічної допомоги дітям від народження до 3 років 3 порушенням розвитку або ризиком його виникнення. В період новонародженості організм дитини $є$ лабільним. Закономірний розвиток дитини пов'язаний 3 його пластичністю, яка $є$ максимально високою на перших стадіях виявлення відхилень. Пластичність НС полягає в можливості компенсації і заміщення, здорові ділянки мозку беруть на себе функції пошкоджених [8; 5].

Власне особливості закономірного розвитку систем дитячого організму вказують на значимість первинного виявлення та запобігання проблем шляхом корекції порушених функцій у дітей раннього віку, починаючи 33 місяців і до одного року, оскільки молодий організм перебуває в стадії розвитку і удосконалення всіх систем і функцій. Серйозну проблему тягне за собою порушення моторного, психічного та мовного розвитку внаслідок пізнього первинного звернення (у дошкільному віці) до спеціалізованих закладів та початку первинної корекційної роботи. Отже, проведення корекційних розвиваючих занять методом Бобат для дітей дошкільного віку з ураженням ЦНС, враховуючи гендерні особливості, $є$ актуальною проблемою сьогодення.

3 ряду методів (Войта, кондуктивна педагогіка Петьо, Фельдкрайза), що сприяють корекції психомоторного стану новонароджених дітей та дітей дошкільного віку, варто відзначити метод Бобат. Адже саме завдяки йому стало можливим одночасно провести корекцію психофізичного стану дітей дошкільного віку без додаткових втручань. Метод Бобат широко використовується за кордоном, в таких країнах, як Чехія, Словенія, Швейцарія, США, а від недавнього часу - і в країнах СНД (Вірменія, Україна, Латвія) [5; 12].

Концепція методу була обгрунтована ще в 40-х роках XX століття подружжям Бертою і Карлом Бобат, яка базувалась на клінічних спостереженнях. Метод Бобат має істотний вплив на загальний розвиток принципів корекції психофізичного стану дітей 3 ураженням ЦНС дошкільного віку [3; 11].

Метою статті $є$ визначення ефективності застосування корекційних розвиваючих занять методом Бобат для дітей дошкільного віку з ураженням ЦНС, ураховуючи гендерні особливості.

Існує думка, що немає особливих гендерних відмінностей у дітей дошкільного віку в моторному розвитку. Однак, є ряд об’єктивних відмінностей у проведенні корекційних занять дівчат i хлопців, пов'язаних із фізіологічними особливостями їх організмів [10].

Наприклад, дівчата в середньому менші і легші за хлопців, а ріст м'язової маси у хлопчиків відбувається швидше. Центр маси тіла дівчат знаходиться нижче, ніж у хлопців у зв'язку з особливостями статури - у дівчат більш довгий тулуб і коротші нижні кінцівки, а також дівчатка, в силу більш швидкого дозрівання організму, швидше за хлопців досягають своїх фізичних, у тому числі і силових, кондицій. Дівчата в середньому мають більшу гнучкість і високий больовий поріг у порівнянні з хлопцями [2; 9].

Отже, диференційований підхід на заняттях корекційною розвиваючою методикою Бобат із урахуванням статевих відмінностей психомоторного розвитку та фізичного виховання хлопців і дівчат може здійснюватися за таким напрямком, як пред'явлення різних вимог до виконання одних і тих самих рухів (В. А. Мануйлова і В. М. Зуєва, 1991): чіткості, ритмічності, витрати додаткових зусиль (для хлопчиків); пластичності, виразності, граціозності (для дівчат) [5].

Дошкільний вік - дуже важливий етап у житті дитини. У цей період відбувається функціональна досконалість. Відомо, що цей вік є вирішальним етапом у формуванні фундаменту фізичного і психічного розвитку дитини. У цей період йде інтенсивний розвиток органів і становлення функціональних систем організму [3; 12].

Метою статті $\epsilon$ аналіз розвитку основних рухових навичок у дітей дошкільного віку з ураженням ЦНС на корекційних заняттях за методом Бобат, враховуючи гендерні особливості [2; 4].

Власне сучасний метод Бобат включає в себе лікування положенням, що сприяє зменшенню впливу патологічних рефлексів (АСШТ, хоботковий, смоктальний, пошуковий, Моро, перехресний рефлекс екстензорів і т.п.), а саме використання спеціалізованих укладок тіла дитини. Другим аспектом методики $\epsilon$ виконання вправ, які зменшують або блокують вплив цих рефлексів, і стимуляція зон краніопунктури. Метод Бобат базується i на розвитку координаційних здібностей і основних фізичних якостей: спритності, сили, швидкості, гнучкості, витривалості, дрібної і великої моторики, просторових уявлень і орієнтацій, мислення та пам'яті, профілактики та лікування контрактур та деформацій. Хотілося б зазначити, що навчання навичок самообслуговування та особистої гігієни, основниих етапів догляду за особливою дитиною, правильного вибору ігор та іграшок, відповідних індивідуальним можливостям - це найважливіші складові частини методики корекції психофізичного стану дітей дошкільного віку з ураженням ЦНС за методом Бобат [6; 9].

В основі методу лежить вплив на «ключові точки контролю» (голова, тулуб, плечі, таз, долоні, стопи) зони тіла, в яких проявляється міцність рецепторів. Впливаючи на дистальні та проксимальні ключові точки, можна найбільш ефективно контролювати i 
змінювати пози і рухи в тих частинах тіла, де збільшується м'язовий тонус. Основною метою терапії є поліпшення постурального контролю і селективних рухів $з$ метою оптимізації рухових функцій шляхом фасилітації. При цьому вплив корекційного педагога здійснюється під час рухової активності та спрямований на пригнічення патологічних рухових моделей $і$ стимулювання розвитку елементарних рухових навичок $[10 ; 16]$.

Необхідно відзначити, що метод Бобат має сформовані принципи: придушення рефлекторної тонічної діяльності, що веде до нормалізації м'язового тонусу; сприяння включенню рухових реакцій у відповідності 3 послідовністю їх розвитку $[1 ; 15]$.

Контроль ефективності проведення занять колекційною розвиваючою методикою Бобат здійснюється за допомогою «Картки-тесту рухових можливостей дітей від 3 місяців до повноліття», яка якісно визначає етапи психомоторного розвитку дитини $[6 ; 11]$.

Оцінка впливу методики Бобат здійснювалась на підставі шкали, яка передбачала встановлення рівня рухової активності дитини в окремих положеннях. Кожна навичка оцінюється за 6-бальною шкалою, де:

5 балів (відмінний) - дитина виконує нормальний активний рух;

4 бали (добрий) - дитина може самостійно перейти в бажане положення, але рух має незначні деталі, які свідчать про його недосконалість;

3 бали (достатній) - дитина може самостійно перейти в бажане положення, але робить це аномальним чином;

2 бали (задовільний) - дитина може втриматися без підтримки в бажаному положенні після пасивного прийняття пози;

1 бал (незадовільний) - дитина може пасивно прийняти бажане положення, але не може утриматися в ньому;

0 балів (абсолютно незадовільний) - присвоювалось за умови неможливості прийняти постуру ні пасивно, ні активно, оскільки спастичність є занадто сильною, навіть для того, щоб посадити дитину в бажаному положенні.

Шкала настільки деталізована, що дозволяє спостерігати за динамікою психомоторного розвитку дітей від 3 місяців до повноліття. Карта охоплює всі основні моменти психомоторного розвитку дитини, $\epsilon$ простою в застосуванні, не вимагає великих часових витрат у заповненні і підрахунку результатів. Завдяки цьому тесту стало можливим простежити та оцінити динаміку формування та оволодівання елементарними руховими навичками $[6 ; 12]$.

Однак, раніше в оцінці ефективності проведення корекційних занять методом Бобат враховувалася лише диференціація за віком та нозологічною групою. Гендерні різниці не фіксувалися. Фізіологічні особливості пристосувальних і фізичних можливостей хлоп- чиків і дівчаток мають відмінності, що також необхідно враховувати [8; 13].

Експеримент проходив на базі ООЦРДІ «Майбутнє». На початку і наприкінці проведення корекійних розвиваючих занять методом Бобат були обстежені 30 дітей, з яких 15 дівчаток і 15 хлопчиків 3-6 років з органічним ураженням та ЦНС. Діти вперше займалися за методом Бобат, курс включав 10 занять тривалістю 40 хвилин, кожні 2-3 дні. Загалом кількість таких курсів $\epsilon$ необмеженою та може повторюватися кожні 2-3 місяці.

У таблиці 1 представлено динаміку оволодівання елементарними руховими навичками в окремих положеннях на початку першого курсу Бобат терапії у обстеженої категорії дітей.

3 табл. 1 та 3 табл. 2 власне можна відзначити, що за курс застосування методу Бобат рухові навички у положенні на спині у дівчаток дещо покращились, в першу чергу за рахунок збільшення відмінних варіантів, які змінились з 52\% до $62 \%$, у хлопців - з 20\% до $25 \%$. Певне покращення відзначалось в оцінках рухових навичок у положенні на животі - за рахунок можливості самостійно приймати та утримувати позу. Заслуговує на увагу можливість зайняття пози у положенні сидячи, де показник збільшився з 40\% на $46 \%$ у дівчаток та з 20\% до $25 \%$ - у хлопців. У положенні стоячи на чотирьох на початку курсу проведення корекційних розвиваючих занять методом Бобат $60 \%$ із загальної кількості дівчат та $20 \%$ хлопців, а вже наприкінці курсу - 70\% дівчат та 24\% хлопців змогли самостійно перейти у задане положення, що дозволяє стверджувати про ефективний вплив запропонованої методики на м'язи спини та кінцівок. Не менш значущим $є$ те, що один курс корекційнорозвиваючої методики Бобат не мав суттєвого впливу на формування елементарних рухових навичок у вихідному положенні на животі, коли показник в положенні на спині збільшився на $10 \%$ у дівчаток. Навички ходьби (неможливість їі виконання) збільшилась 3 $0 \%$ на початку курсу до 13\% наприкінці курсу у дівчаток за рахунок появи можливості вільного оволодівання більш легкими елементарними руховими навичками (табл. 1).

Вагомим ефектом курсу корекційно-розвиваючих занять за методом Бобат слід вважати суттєве покращення можливості у дітей з ураженням ЦНС виконувати стійку на одній нозі: збільшення показника відмінної оцінки до 4\% у дівчаток та на 5\% у хлопців, що свідчить про покращення функції вестибулярного апарату та пропріоцептивної чутливості. Значущим $є$ те, що один курс занять за методом Бобат має і суттєвий вплив на формування навички ходьби: $52 \%$ iз загальної кількості дівчаток та 24\% хлопців оволоділи цією навичкою. Слід констатувати, що за всіма дослідженими руховими навичками відбулось більш-менш виражене покращення. 
Динаміка розподілу оцінок оволодівання елементарними руховими навичками дітей дошкільного віку з ураженням ЦНС за час курсу корекційних занять методом Бобат (\%)

\begin{tabular}{|c|c|c|c|c|c|c|c|c|c|c|}
\hline $\begin{array}{l}\text { Рівні сформова- } \\
\text { ності елементар- } \\
\text { них рухових } \\
\text { навичок }\end{array}$ & $\stackrel{\Xi}{E}$ & 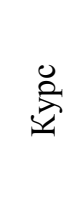 & 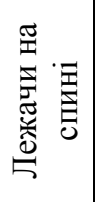 & 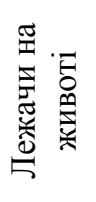 & 疍 & 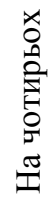 & 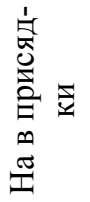 & 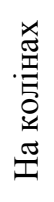 & $\begin{array}{l}\pi \\
0 \\
0 \\
0 \\
0 \\
x\end{array}$ & 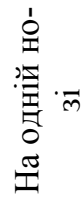 \\
\hline \multirow{4}{*}{ Відмінний } & Хлопці & \multirow{2}{*}{ п. к. } & 20 & 20 & 21 & 20 & 40 & 36 & 19 & 15 \\
\hline & Дівчата & & 52 & 45 & 40 & 60 & 50 & 56 & 45 & 34 \\
\hline & Хлопці & \multirow{2}{*}{ к. к. } & 25 & 25 & 26 & 24 & 58 & 37 & 24 & 20 \\
\hline & Дівчата & & 62 & 56 & 46 & 70 & 56 & 70 & 52 & 38 \\
\hline \multirow{4}{*}{ Добрий } & Хлопці & \multirow{2}{*}{ п. к. } & 56 & 50 & 50 & 50 & 15 & 20 & 35 & 30 \\
\hline & Дівчата & & 15 & 15 & 27 & 9 & 5 & 15 & 30 & 48 \\
\hline & Хлопці & \multirow{2}{*}{ к. к } & 58 & 55 & 52 & 52 & 20 & 25 & 30 & 35 \\
\hline & Дівчата & & 27 & 35 & 27 & 15 & 20 & 15 & 20 & 48 \\
\hline \multirow{4}{*}{ Достатній } & Хлопці & \multirow{2}{*}{ п. к. } & 9 & 15 & 20 & 30 & 25 & 25 & 0 & 19 \\
\hline & Дівчата & & 7 & 10 & 20 & 0 & 7 & 15 & 9 & 10 \\
\hline & Хлопці & \multirow{2}{*}{ к. к } & 10 & 9 & 15 & 24 & 20 & 20 & 5 & 20 \\
\hline & Дівчата & & 23 & 17 & 4 & 9 & 0 & 0 & 0 & 8 \\
\hline \multirow[t]{4}{*}{ Задовільний } & Хлопці & \multirow{2}{*}{ П. к. } & 15 & 5 & 0 & 0 & 5 & 20 & 10 & 10 \\
\hline & Дівчата & & 23 & 17 & 4 & 9 & 0 & 0 & 0 & 8 \\
\hline & Хлопці & \multirow{2}{*}{ к. к } & 7 & 10 & 7 & 0 & 2 & 15 & 12 & 20 \\
\hline & Дівчата & & 3 & 9 & 0 & 0 & 4 & 0 & 7 & 9 \\
\hline \multirow[t]{4}{*}{ Незадовільно } & Хлопці & \multirow{2}{*}{ п. к. } & 0 & 0 & 9 & 0 & 5 & 1 & 27 & 10 \\
\hline & Дівчата & & 3 & 13 & 9 & 0 & 9 & 5 & 16 & 0 \\
\hline & Хлопці & \multirow{2}{*}{ к. к } & 0 & 3 & 0 & 0 & 0 & 3 & 25 & 5 \\
\hline & Дівчата & & 13 & 9 & 0 & 9 & 5 & 16 & 0 & 13 \\
\hline \multirow{4}{*}{$\begin{array}{ll}\text { Абсолютно } & \text { не- } \\
\text { задовільний } & \end{array}$} & хлопці & \multirow{2}{*}{ п. к. } & 0 & 0 & 0 & 0 & 0 & 0 & 0 & 15 \\
\hline & дівчата & & 0 & 0 & 0 & 5 & 0 & 9 & 0 & 0 \\
\hline & хлопці & \multirow{2}{*}{ к. к } & 0 & 0 & 0 & 0 & 0 & 0 & 4 & 0 \\
\hline & дівчата & & 0 & 0 & 0 & 0 & 0 & 0 & 0 & 0 \\
\hline
\end{tabular}

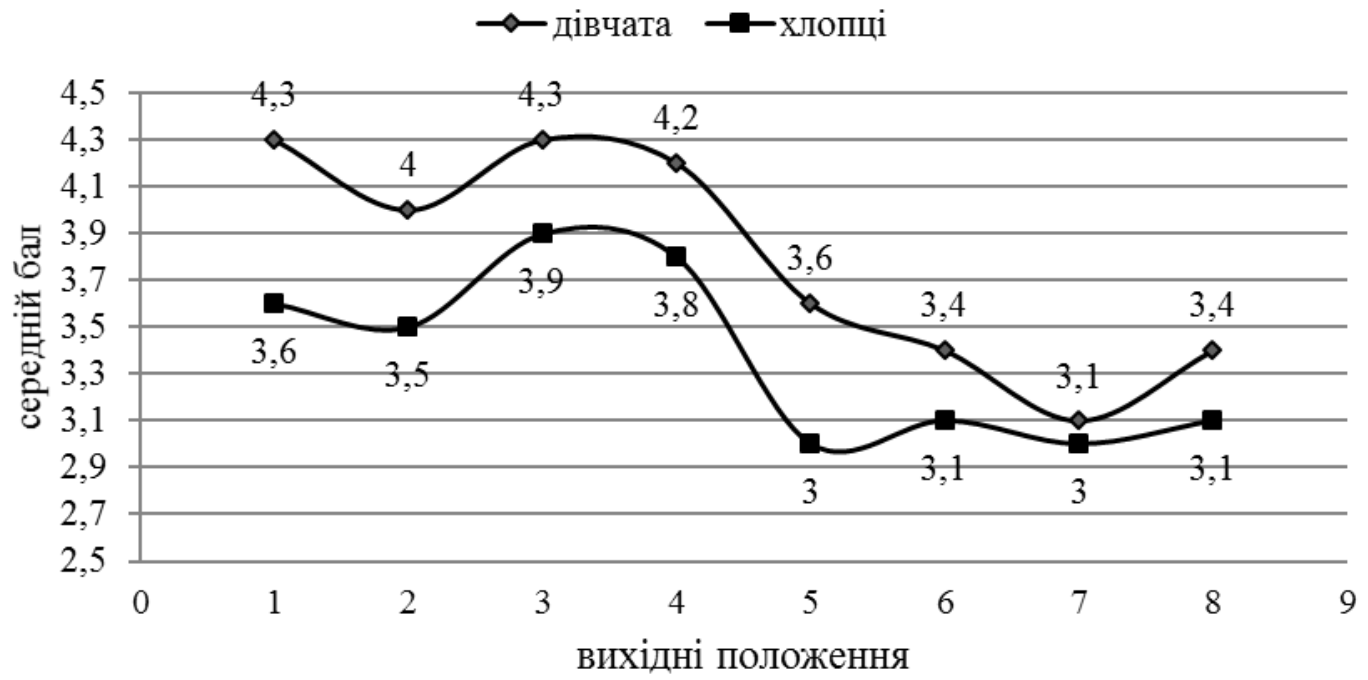

Рис. 1. Оичінка рухових навичок на початку курсу корекиійно-розвиваючих занять методом Бобат; вихідні положення:1 - лежачи на спині; 2 -лежачи на животі; 3 - сидячи; 4 - на чотирьох кінцівках; 5 навприсядки; 6-на колінах; 7 -ходьба; 8-на одній нозі. 
За рис. 1 та рис. 2 визначається, що в основних вихідних положеннях оцінка моторних можливостей і виконання елементарних рухових навичок у дівчаток $\epsilon$ набагато вищою. В подальшому при проведенні корекційних занять у дівчаток змінився показник у вихідних положеннях в середньому на 1 бал, коли у хлопців - тільки на 0,5 балу (рис. 2). Це дійсно свідчить про те, що у дівчаток швидше відбувається до- зрівання і адаптація організму, ніж у хлопчиків, а стимуляція психомоторного розвитку відбувається стрімкіше. Так само дівчата мають більшу гнучкість i вищий больовий поріг у порівнянні з хлопчиками цей фактор так само сприяє підвищенню динаміки розвитку рухових навичок у решті вихідних положень.

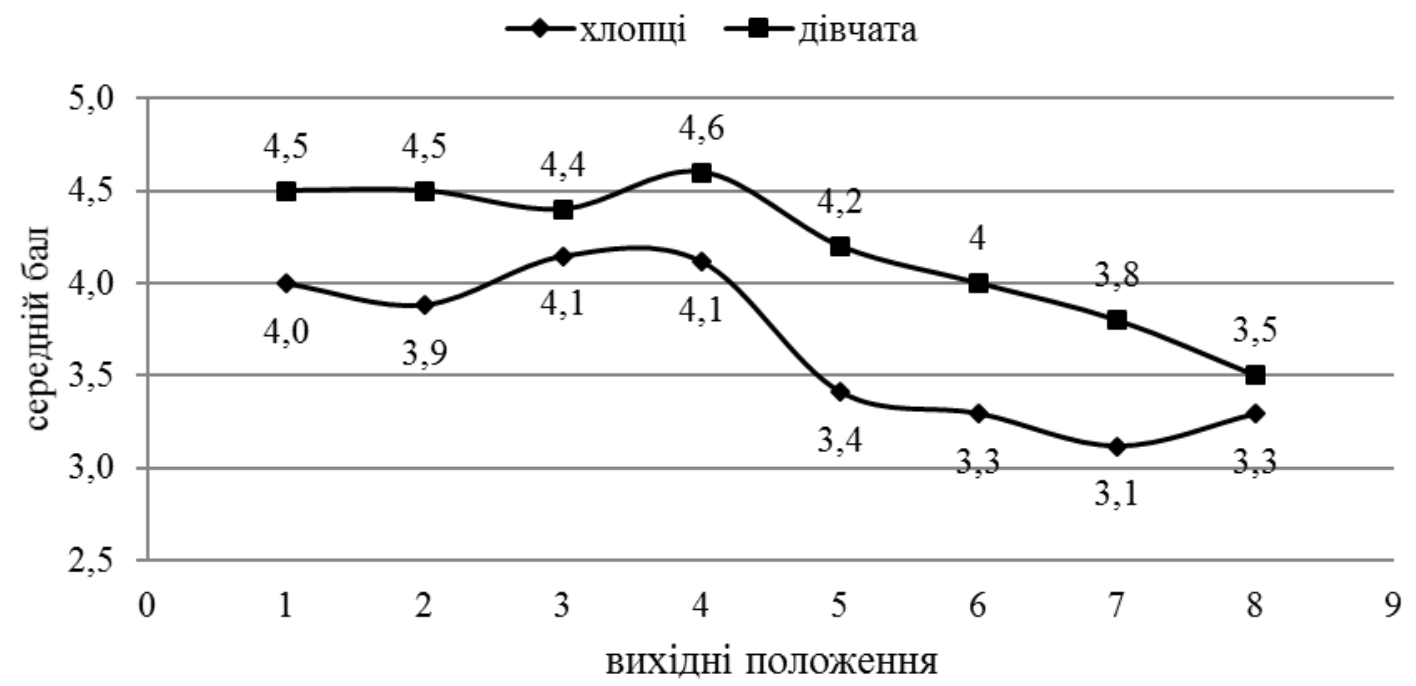

Рис. 2. Очінка рухових навичок наприкінці курсу корекційно-розвиваючих занять методом Бобат; 1 - лежачи на спині; 2 - лежачи на животі; 3 - сидячи; 4 - на чотирьох кінцівках; 5 - навприсядки; 6 - на колінах; 7 -ходьба; 8-на одній нозі.

Наголошується, що розвиток координаційних здібностей у хлопчиків відбувається набагато швидше (Н. Бочарова, 1997), але за зміною середнього балу у вихідному положенні стоячи на колінах і на одній нозі ця динаміка не просліджується, оскільки у дівчаток цей показник значно перевищує. Це ще раз показує, що хло- пчикам треба більш часу для адаптації. Значно покращилися показники переходу в положення навприсядки та самостійного утримування в положенні на колінах і у хлопців, і у дівчат, як за індивідуальними оцінками (рис. 1; рис. 2), так і за пересічними (табл. 2).

Приріст оцінок рухових навичок дітей доикільного віку з ураженням ЦНС під час курсу проведення корекції психомоторного розвитку методом Бобат

Таблиця 2.

\begin{tabular}{|c|c|c|c|c|c|c|c|c|c|}
\hline Показник & Група & 1 & 2 & 3 & 4 & 5 & 6 & 7 & \\
\hline \multirow{2}{*}{ Різниця пересічних балів } & Дівчата & 0,2 & 0,3 & 0,1 & 0,3 & 0,2 & 0,1 & 0,1 & 0,3 \\
\hline & Хлопці & 0,1 & 0,1 & 0,2 & 0,1 & 0,2 & 0,3 & 0,3 & 0,2 \\
\hline
\end{tabular}

Примітка: 1- лежачи на спині; 2 - лежачи на животі; 3 - сидячи; 4 - на чотирьох; 5 - на в присядки; 6 - на колінах; 7 - ходьба ; 8 - на одній нозі.

Ураховуючи те, що вимоги до виконання одних і тих самих рухів (чіткості, ритмічності, витрати додаткових зусиль (для хлопчиків); пластичності, виразності, граціозності (для дівчаток)) були різними, є суттєві відмінності в оволодіванні руховими навичками у представників різної статі, в залежності від фізіологічних особливостей організму.

Останнє підтверджується даними, наведеними у табл. 1 та табл. 2, отже можна стверджувати, що після першого курсу занять корекційною методикою Бобат відбулося суттєве покращення навички стояння на колінах, оволодівання вільною ходьбою, відбулися перебудови у нервово-м'язовому апараті тулуба та нижніх кінцівок, вестибулярному апараті як хлопців, так і дівчат. Дані, отримані у нашому експериментальному дослідженні, показали, що перший курс розвиваючих занять за методом Бобат сприяє оптимізації м'язового тонусу в різній мірі виразності. При виконанні деяких рухових тестів відзначається односпрямоване покращення. Визначається, що заняття за методом Бобат сприяють почерговому становленню функції опорно-рухового апарату.

Можна припустити, враховуючи фізіологічні особливості чоловічої та жіночої статі, що при подальших 
курсах корекційних занять методом Бобат показники рухової активності дівчат не будуть значно змінюватись, а от показники хлопців, вірогідно, зростуть.

Висновки та перспективи подальших досліджень. Результати проведеного дослідження дозволяють стверджувати, що метод Бобат має власне місце у системі корекції психофізичного стану дітей дошкільного віку 3 органічним ураженням ЦНС. Останнє обгрунтовується достатньо вагомими ефектами, які характеризуються позитивною динамікою в оволодіванні елементарними руховими навичками дітей дошкільного віку 3 урахуванням гендерних особливостей.

\section{ЛІТЕРАТУРА}

1.Бадалян Л. О. Дитячі церебральні паралічі / Л. О. Бадалян, Л. Т. Журба, О. В. Тимоніна. - К. : Здоров'я, 1988. - 328 с.

2 Бєсєда В. В. До питання оцінки фізичної підготовленності дітей дошкільного віку /

В. В Бєсєда, О. П. Романчук // Зб. наук. Праць Кам'янець-Подільського національного університету імені Івана Огієнка. - Кам'янець-Подільський: Медобори, 2012. - №29(2). - С. 237-243.

3.Бобат К. Моторні дефекти у пацієнтів 3 церебральним паралічем / К. Бобат. - Саффолк: Вільна преса,1966. - 56 с.

4.Бобат-концепція. Теорія та клінічна практика в неврологічній реабілітації. - Нижній Новгород: Кирилиця, 2013. - $320 \mathrm{c}$.

5.Бочарова М. Деякі питання диференційованого підходу у фізичному вихованні хлопчиків і дівчаток / М. Бочарова// Дошкільна виховання. - Київ : Світич, 2005. - №12. - С. 72-75.

6.Буховець Б. О. Бобат терапія в корекції психомоторного розвитку дітей з органічними ураженнями / Б. О. Буховець // Наука і освіта. - Одеса: наук.практ. журн. Півд. наук. Центру НАПН України, 2014. - № 8. - C. 30-35.

7.Дамулін В. В. Психогеннірухові порушення / В. В. Дамулін, Є. Н. Яворська, О. Є. Ратбиль // Неврологічний журнал. - М. :Медицина, 2007. - № 2. - С. 65-68.

8.Колкер I. А.Дитячі Цербральні параліч: Інструментальна діагностика. Лікування / I. А. Колкер,

\section{REFERENCES}

1. Badalyan, L. O., Zhurba, L. T., Timonina, O. V. (1988). Dytiachi tserebralni paralschi [Child cerebral palsy]. Kyiv: Zdorove [in Ukrainian].

2. Beseda, V. V., Romanchuk, O. P. (2012) Do pytannia otsinky fizychnoi pidhotovlennosti ditei doshkilnoho viku [Revisiting the issue of the assessment of preschool children's physical fitness]. Zb. nauk. Prats Kamianets-Podilskoho natsionalnoho universytetu imeni Ivana Ohiienka - Collection of scientific works of Kamenets Podilskyi national university named after Ivan Ihiienko, 19(2), 237-243 [in Ukrainian].
Слід констатувати, що за деякими дослідженими елементарними руховими навичками констатується покращення, погіршення в оволодіванні у хлопців та дівчат ходьбою, стоянням на одній нозі відбулось за рахунок стрімкого поліпшення виконання більш простих навичок (сидіння, стояння на колінах).

Перспективи подальших досліджень полягають у вивченні особливостей психомоторного розвитку дітей дошкільного віку з ураженням ЦНС під час проведення курсу корекційних розвиваючих занять методом Бобат.

В. Є. Михайленко, І. П. Шмакова. - Одеса: Пласке 3АT, 2006. - $312 \mathrm{c}$.

9.Міщук Т. Чи буде в Україні надаватися послуга «раннє втручання» / Т Міщук // НейрoNews. Хвороби дитячого віку в психіатрії та неврології. - Київ: Аванпост- Прим, 2011. - №5 (3). - С. 4-10.

10.Ненсі Р. Фінні Дитина 3 церебральним паралічем. Допомога. Догляд. Розвиток. Книга для батьків / Р. Ненсі. - М. : Теревінф, 2009. - 330 с.

11.Осокіна Т. І. Фізична культура в дитячому саду / Т. І. Осокіна. - М. : Просвіта, 1986. - С. 38-40.

12.Робєнеску Н. Нейромоторне перевиховання / Н. Робенеску. -Бухарест: СТМ, 1972. - 268 с.

13.Романчук О. П. Методичні аспекти проведення та організації масажної гімнастики у ранньому віці / О. П. Романчук, В. В. Бєсєда // Медична реабілітація, курортологія, фізіотерапія. - К.: 2009. - № 4 (60). - С. 37-40.

14.Сапін М. П. Анатомія та фізіологія людини (3 віковими особливостями дитячого організму): Навчальний посібник для студентів середовищ. пед. навч. Закладів / М. П. Сапін, В. І. Сівоглазов. - М.: Академія, 1997. - С. 52-56.

15.Тарасун В. В. Психолого-педагогічна допомога дітям перед дошкільного віку з особливостями в розвитку: напрями реалізації. Монографія / В. В. Тарасун.- К.: Видавництво Національного педагогічного університету імені М.П. Драгоманова, 2012. - 412 с.

16.Forssberg H. Impaired grip-lift synergy in children with unilateral brain lesions / H. Forssberg, A. C Eliasson // Brain. - 1999. - №6. - P.1157-1168.

3. Bobat, K. (1966). Motorni defekty u patsientiv z tserebralnim paralichem [Motor defects in patients with cerebral palsy]. Saffolk: Svobodna presa [in Ukrainian].

4. Bobat Concept (2013). Teoriya ta klinichna praktika $v$ nevrologii $i$ reabilitacii [Theory and clinical practice in neurology and rehabilitation]. Nizhniy Novgorod: Kirilitsya [in Ukrainian].

5. Bocharova, M. (2005). Deyaki pytannia diferentsiiovanoho pidkhodu u fizichnomu vykhovanni hlopchikiv i divchatok [Some issues of differentiated approach in physi- 
cal training of boys and girls]. Doshkilne vihovannya - Preschool education, 12, 72-75. Kyiv: Svitich [in Russian].

6. Bukhovets, B. O. (2014). Bobat terapiya v korektsii psykho-motornoho rovytku ditei z orhanichnymy urazhennaymy [Bobath therapy in the correction of psychomotor development of children with organic lesions]. Nauka i osvita-Science and education, 8, 30-35 [in Ukrainian].

7. Damulin, V. V., Trushina, E. N., Yavorska, S. A., Ratbilo, E. (2007). Psykhogenni rukhovi porushennya [Psychogenic movement disorders]. Nevrologschniy zhurnal - Neurological journal, 2, 65-68. Moscow: Meditsina [in Russian].

8. Kolker, I. A., Mihaylenko, V. E., Shmakova, I. P. (2006). Dytiachyi tserbralnyi paralich: Instrumentalna diagnostyka. Likuvannia [Cerebral palsy: Instrumental diagnostics. Treatment]. Odesa: Plaske ZAT [in Russian].

9. Mishhuk, T. (2011). Chy bude v Ukraini nadavatysia posluha «rannie vtruchannya» [Will Ukraine be granted the service "early intervention"?]. Yevronews. Khvoroby dytiachoho viku v psykhiatrii ta nevrolohii EuroNews. Child diseases in psychiatry and neurology, 5, 4-10. Kyiv: Avanpost-prim [in Ukrainian].

10. Nensi, R. Finni (2009). Dytyna z tserebralnym paralichem. Dopomoha. Dogliad. Rozvytok [Child with Cerebral Palsy. Help. Care. Development. Book for Parents]. Moscow: Terevinf [in Ukranian].

11. Osokina, T. I. (1986). Fizichna kultura $v$ dityachomu sadu [Physical education in a kindergarten]. Moscow: Prosvita [in Russian].

12. Robienesku, N. (1972). Neiromotorne perevihovannia [Neyromotor learning]. Buharest: YETM [in Russian].

13. Romanchuk, A. P., Beseda, V V. (2009). Metodichni aspekty provedennia ta orhanizatsii masazhnoi himnastyky u ranniomu vitsi [Methodological aspects of massage gymnastics organization at the early age]. Medichna reabilitatsiia, kurortolohiia, fizioterapiia - Medical rehabilitation, cultorology, physiotherapy, 4, $37-40$ [in Ukranian].

14. Sapin, M. P., Sivoglazov, V. I. (1997). Anatomiia ta fiziolohiia liudyny (z vikovymy osoblyvostiamy dytiachoho orhanizmu): Navchalniy posibnyk dlia studentiv seredovisch. ped. navch. Zakladiv [Anatomy and Physiology (with age characteristics of the child's body): Textbook for students of pedagogical universities]. Moscow: Akademiia [in Ukranian].

15.Tarasun, V. V. (2012). Psykholoho-pedahohichna dopomoha ditiam pereddoshkilnoho viku z osoblivostiamy $v$ rozvytku: napriamy realizatsii. Monografiia [Psychopedagogical assistance to preschool children with features in development: directions of realization. Monograph.]. Kyiv: Vydavnytstvo Natsionalnoho pedahohichnoho universitetu imeni M. P. Drahomanova [in Russian].

16.Forssberg, H., Eliasson, A. C., Redon-Zouitenn, C. (1999). Impaired grip-lift synergy in children with unilateral brain lesions. Brain, 6, 1157-1168 [in English].

Божена Олеговна Буховець, аспирант кафедры теории и методики физического воспитания, лечебной физкультуры и спортивной медицины, Южноукраинский национальный педагогический университет имени К. Д. Уиинского, ул. Фонтанская дорога, 4, г. Одеса, Украина

\section{ЭФФЕКТИВНОСТЬ ПРОВЕДЕНИЯ КОРРЕКЦИОННЫХ РАЗВИВАЮЩИХ ЗАНЯТИЙ ПО МЕТОДУ БОБАТ ДЛЯ ДЕТЕЙ ДОШКОЛЬНОГО ВОЗРАСТА С ПОРАЖЕНИЕМ ЦНС С УЧЕТОМ ГЕНДЕРНЫХ ОСОБЕННОСТЕЙ}

Статья посвящена проблеме определения эффективности применения метода Бобат как основной методики коррекции психофизического состояния детей дошкольного возраста с поражением центральной нервной систем с учетом гендерных особенностей. В данном опыте нами для оценки эффективности проведения коррекционных развивающих занятий по методу Бобат с учетом гендерных особенностей была использована собственная адаптированная шкала «Карта-тест двигательных возможностей детей от 3 месяцев до совершеннолетия», благодаря которой стало возможным детально определить этапы психомоторного развития детей дошкольного возраста. Учитывая универсальность, доступность и информативность данного теста, стало возможным оценить эффективность применения метода Бобат при коррекции психофизического состояния детей дошкольного возраста с поражением центральной нервной системы, учитывая гендерные особенности. Основой эксперимента стало оценивание элементарных двигательных навыков в отдельных положениях в начале и динамику их формирования в конце курса проведения коррекционных развивающих занятий по методу Бобат у детей дошкольного возраста с поражением центральной нервной системы с учетом гендерных особенностей. В результате эксперимента было определено, что за курс проведения занятий по методу Бобат существенно улучшилось формирование двигательных навыков в исходном положении лежа на спине у девочек. Положительная динамика прослеживается в формировании двигательных навыков в исходном положении стоя на четвереньках как у мальчиков, так и у девочек, что позволяет говорить об эффективном влиянии предложенной методики на мышцы спины, верхних и нижних конечностей. Следует констатировать, что по всем исследованным двигательным навыкам состоялось выраженное улучшение, однако, прослеживалось и ухудшение формирования некоторых сложных навыков (ходьба, стояние на одной ноге) за счет стремительного улучшения выполнения более простых (сидение, стояние на коленях) упражнений. Учитывая результаты данного исследования, стало 
возможным констатировать, что коррекционные развивающие занятия по методу Бобат с учетом гендерных особенностей способствуют поочередному становлению функций опорно-двигательного аппарата детей дошкольного возраста с поражением центральной нервной системы.

Ключевые слова: психомоторное развитие, дети дошкольного возраста, метод Бобат, центральная нервная система, коррекционные развивающие занятия.

Bozhena Bukhovets, post-graduate student, Department of Theory and Methods of Physical Education, Physical Therapy and Sports Medicine, South Ukrainian National Pedagogical University named after K. D. Ushynsky, 4, Fontanska Doroha Str., Odesa, Ukraine

\section{EFFICIENCY OF BOBATH CORRECTIONAL REMEDIAL EXERCISES FOR} PRESCHOOLERS WITH CEREBRAL PALSY CONSIDERING THEIR GENDER PECULIARITIES

The article deals with the issue of the efficiency of applying Bobath therapy as the main method of the correction of psycho-physical state of preschoolers with central nervous system damages considering their gender. In order to assess the efficiency of the correctional remedial exercises the adapted scale "Testing motor skills of children aged from 3 months to the lawful age" was used. It helped to estimate the stages of psychomotor development of preschoolers. Due to its flexibility, accessibility and informative value it became possible to assess the effectiveness of the Bobath therapy for the correction of the psychophysical state of the above mentioned children. The experiment was based on the estimation of the basic motor skills in certain positions at the beginning and the dynamics of their formation at the end of the course of Bobath correctional remedial gymnastics. Positive results in the formation of motor skills in the initial position standing on all fours of both boys and girls have been observed. It confirms the effective influence of the proposed method on the back muscles, upper and lower limbs. It should be stated that all the examined motor skills have improved, however, the deterioration in the formation of some complex skills (walking, lifting a leg) because of the rapid improvement of performing more simple exercises (sitting, kneestanding) has been noted. Considering the research results it should be emphasized that Bobath correctional remedial gymnastics contributes to successive formation of locomotor system functions of preschoolers with central nervous system damage.

Keywords: psychomotor development, preschoolers, the Bobath method, central nervous system, remedial gymnastics.

Рецензент: д. мед. н., проф. О. П. Романчук

Подано до редакиії 14.04.2016 